\title{
A high-elevation Holocene pollen record from Iztaccíhuatl volcano, central Mexico
}

\author{
Socorro Lozano-García ${ }^{1 *}$ and Lorenzo Vázquez-Selem ${ }^{2}$
}

\author{
('Instituto de Geología, Universidad Nacional Autónoma de México, Coyoacán \\ 04510 México, D.F., Mexico; ${ }^{2}$ Instituto de Geografia, Universidad Nacional \\ Autónoma de México, Coyoacán 04510, México, D.F., Mexico)
}

Received 7 July 2003; revised manuscript accepted 2 May 2004

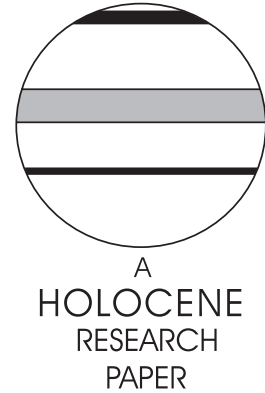

\section{Introduction}

The tectonic and volcanic evolution of the Mexican Volcanic Belt (MVB) during the late Tertiary and Quaternary led to the formation of high stratovolcanos and depressions with endorheic sedimentary basins. This geological province crosses Mexico with a NNW-SSE orientation between $21^{\circ}$ and $19^{\circ} \mathrm{N}$ (Ferrari et al., 1994; Ferrari, 2000). Extensive lakes formed in some of the tectonic depressions, preserving the palaeoenvironmental signal through continuous and semi-continuous sedimentation. Research on late Pleistocene vegetation history and palaeolimnology carried out in the last decade in several sedimentary sequences of the MVB lakes provides information of climatic change and human impact in a region considered the northern limit of the American tropics (Metcalfe et al., 1991; Lozano-García et al., 1993; Xelhuantzi-López, 1994; Lozano-García and Ortega-Guerrero, 1994; 1997; Caballero, 1995; Caballero and Ortega-Guerrero, 1998; Bradbury, 2000; Caballero et al., 2002; Velázquez, 2003).

The pattern of climatic change for the last 20000 years in the central highlands of Mexico is rather complex (Metcalfe et al., 2000). In the Basin of Mexico, one of the most studied areas,

*Author for correspondence (e-mail: mslozano@servidor.unam.mx) several sequences covering the last glacial maximum have been analysed and the pollen data indicate cool and dry conditions. Most of the palaeorecords from central Mexico show climatic oscillations during the transition from the Lateglacial to the Holocene but a clear picture has not yet emerged. Palaeoecological evidence for the early Holocene is contradictory as dry conditions are inferred from palaeolimnological data while pollen stratigraphy suggests an increase in montane mesic taxa. Indications of drier conditions for a short period during the mid-Holocene emerge from several palaeorecords in central Mexico (Grimm et al., 2001). The late Holocene climatic change signal in many of the MVB basins is disrupted by the long history of human occupation. Indications of higher lake levels for the last c. 3000 years in the Basin of Mexico point towards moister climates (Caballero and Ortega, 1998; Caballero et al., 2001, 2002), although most of the late Holocene sediments are lost because of human impact on the environment, making it difficult to define the climatic variability for this interval. In the neighbouring Lerma basin, periods of drought have been documented for the last 1000 years, with low lake levels during the Classic archaeological period (c. AD 800) (Caballero et al., 2002). Most of the existing palaeoecological records come from lake basins between elevations of 1800 and $2600 \mathrm{~m}$, i.e., relatively low areas within 
the MVB. Few published records exist for the mid slopes (around $3000 \mathrm{~m}$ ) of the volcanic mountains (Ohngemach, 1977; Ohngemach and Straka, 1983; Almeida-Leñero, 1997; Caballero et al., 2001) and none for sites above $3100 \mathrm{~m}$.

The aim of this paper is to use the pollen record to document changes in the Holocene plant communities of a high-elevation site $(3860 \mathrm{~m})$ located near the present timberline of Iztaccíhuatl volcano. In addition, new evidence on Holocene glacial advances of Iztaccíhuatl allows an evaluation of the impact of glaciation and related climatic changes on vegetation at local and regional scales.

\section{The site and its environmental context}

The study site is located in a moraine depression of the glacial valley Agua Agua El Marrano (3860 m) on the northwest side of Iztaccíhuatl volcano at $19^{\circ} 12^{\prime} 35.67^{\prime \prime} \mathrm{N}$ and $98^{\circ} 39^{\prime} 57.00^{\prime \prime} \mathrm{W}$. Iztaccíhuatl (5286 m) and Popocatépetl (5452 m) volcanos are part of the Sierra Nevada range, which separates the basins of México and Puebla-Tlaxcala (Figure 1a). The eruptive history of Iztaccíhuatl stratrovolcano consists of two main phases of construction, the old volcanic series with an age of $>600 \mathrm{Ma}$ and the younger volcanic series of $<600 \mathrm{Ma}$ (Nixon, 1989). Several glacial advances have been documented on Iztaccíhuatl during the late Pleistocene and Holocene (White, 1962; Heine, 1988; Vázquez-Selem, 2000), postdating volcanic activity. At present small glaciers cover the summit area of Iztaccíhuatl above $4900 \mathrm{~m}$ (Lorenzo, 1964; White, 2002). In contrast, Popocatépetl volcano has been active throughout the late Pleistocene and Holocene (Siebe et al., 1996) and is still active at present (Martin-Del Pozzo et al., 2002). As a consequence of repeated explosive eruptions, a number of tephra layers from Popocatépetl can be found in the lacustrian beds in the Basin of Mexico (Mooser, 1967; Lambert 1986; Ortega and Newton, 1998; Ortega-Guerrero et al., 2000) and on the slopes of neighbouring mountains, such as Iztaccíhuatl (Heine, 1975; Siebe et al., 1996; Vázquez-Selem, 2000).

The depression from which the core was collected is perched on a structural bench of the valley side-slope (Figure 1a,b). A moraine ridge isolates it from the main valley stream. The depression has internal drainage, but there are no signs of flooding either on the surface or in the sediment column, as volcanic rocks and sediments of the area are highly permeable.
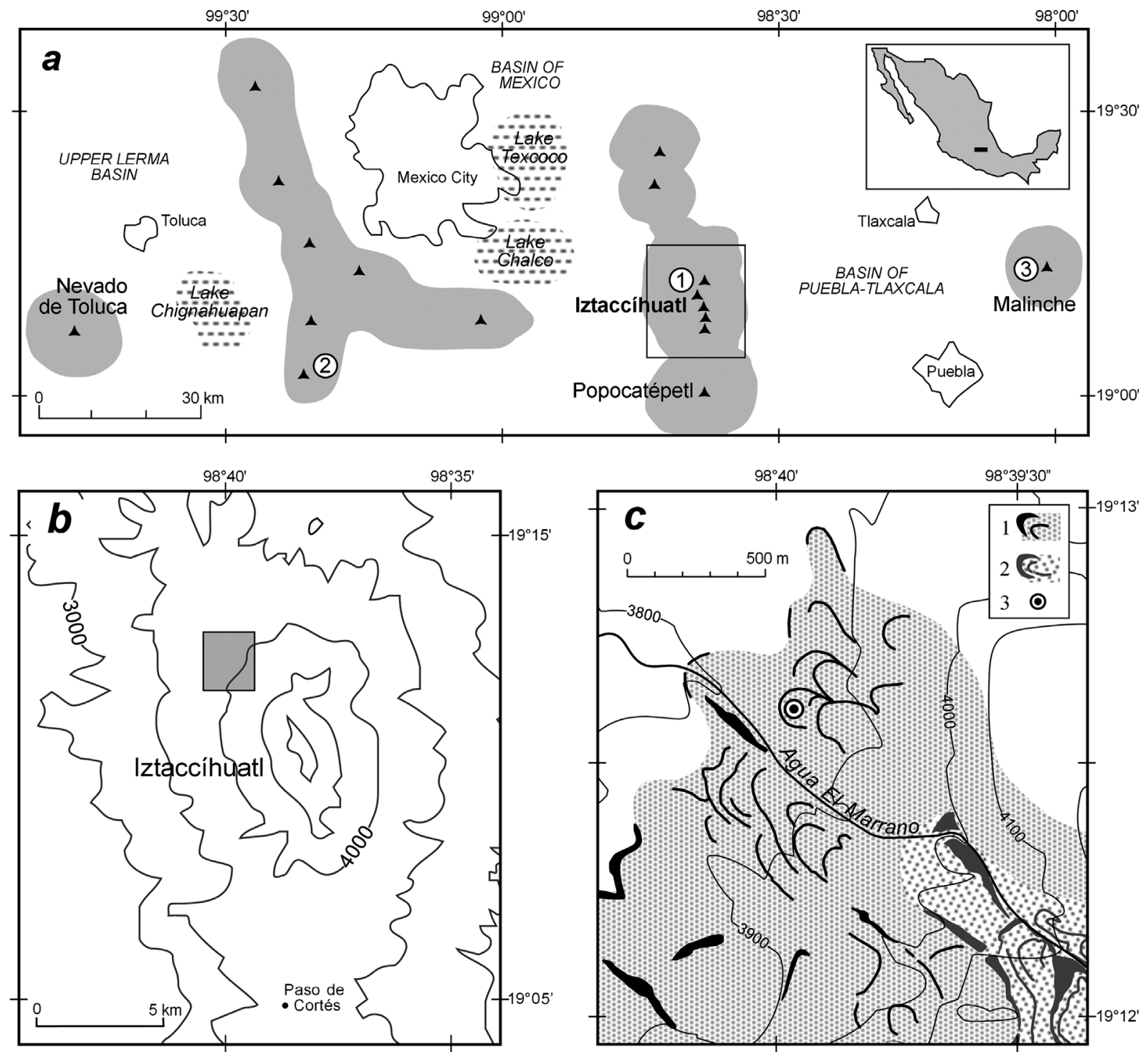

Figure 1 Location of the study area and other sites mentioned in the text. (a) Basins and major stratovolcanoes of central Mexico. 1, Agua El Marrano site; 2, Lake Quila site; 3, Tláloc crater site. (b) Iztaccíhuatl volcano. (c) Northwest Iztaccíhuatl, showing extent of glacial advances around Agua El Marrano valley and coring site. 1, Milpulco-1 glacier area and moraines; 2, Milpulco-2 glacier area and moraines; 
No streams enter the depression. Sediments trapped by the moraine consist of colluvium derived from the inner slopes of the moraine and tephras produced by the main eruptions of Popocatépetl volcano, located $21 \mathrm{~km}$ to the south-southeast. The entire catchment has an area of $c .2$ ha, including $c .0 .5$ ha of the flat accumulation surface covered by bunchgrasses, and c. 1.5 ha of moraine slopes covered by open forest and bunchgrasses.

A revised glacial chronology of Iztaccíhuatl is based on surface exposure cosmogenic nuclide dating $\left({ }^{36} \mathrm{Cl}\right)$ and tephrochronology (Vázquez-Selem, 2000; Vázquez-Selem and Heine, 2004). Inasmuch as the production rates of cosmogenic ${ }^{36} \mathrm{Cl}$ in rocks are estimated mainly from calibrated ${ }^{14} \mathrm{C}$ ages (Phillips et al., 1996), ${ }^{36} \mathrm{Cl}$ ages are assumed to be equivalent to calibrated dates. The chronology includes two glacial advances (Hueyatlaco 1 and 2) between 20000 and 14000 cal. yr BP; rapid glacier retreat between 14000 and 13000 cal. yr BP; a glacier advance (Milpulco-1) and retreat between $\sim 12000$ and $\sim 10500$ cal. yr BP; a short advance (Milpulco-2) peaking by 8300 cal. yr BP, with recession lasting through 7300 cal. yr BP; and a re-advance (Ayoloco) younger than 1000 cal. yr BP, presumably related to the Little Ice Age.

The present altitudinal distribution of vegetation belts in the Sierra Nevada (Iztaccíhuatl and Popocatépetl volcanos) and their diagnostic species have been documented in several studies (Cruz-Cisneros, 1969; Lauer, 1978; Islebe and Velázquez, 1994; Almeida et al., 1994; Velázquez et al., 2000; Rzedowski and Rzedowski, 2001) (Table 1). Vegetation at the coring site is an open community of Pinus hartwegii with bunchgrasses (Calamagrostis tolucensis and Festuca tolucensis). Pinus hartwegii is the only tree species growing above $3600 \mathrm{~m}$ and therefore forming the timberline of the high volcanos in central Mexico. In the Sierra Nevada ranges it is distributed in a belt at altitudes between 3100-3200 m and 3800-4000 m, where a wide ecotone with the alpine bunchgrassland is established, displaying variations depending on local factors (soils, winds, exposure, etc.) (Beaman, 1962; Lauer and Klaus, 1975; Almeida et al., 1994). The mean elevation of the timberline on Iztaccíhuatl is $4020 \mathrm{~m}$, with a standard deviation of $50 \mathrm{~m}$ (Beaman, 1962). The association of $P$. hartwegii and bunchgrasses represents a natural fire climax association (Lauer, 1978). However, man-induced fires apparently have lowered the timberline from its potential elevation of $4250 \mathrm{~m}$ (upper elevation of trees) to its present position of around $4000 \mathrm{~m}$ (Lauer, 1978). It has been hypothesized that the elevation of the timberline on Iztaccíhuatl is controlled by low temperatures (Beaman, 1962) or by low soil temperature in combination with soil moisture deficiency (Lauer, 1978). Mean annual temperature at the timberline in central Mexico (c. $4000 \mathrm{~m}$ ) is $5^{\circ} \mathrm{C}$ (Lauer and Klaus, 1975).

Table 1 High-altitude plant communities in central Mexican mountains and their characteristic species

\begin{tabular}{|c|c|c|}
\hline \multicolumn{3}{|c|}{ Community } \\
\hline Alpine grasslands & \multicolumn{2}{|c|}{ Coniferous forests } \\
\hline $3900-4500 \mathrm{~m}$ & $3460-4000 \mathrm{~m}$ & $2850-3540 \mathrm{~m}$ \\
\hline Festuca livida & Pinus hartwegii & Abies religiosa \\
\hline Arenaria bryoides & Festuca tolucensis & Cupressus lusitanica \\
\hline Calamagrostis & Calamagrostis & Senecio callosus \\
\hline tolucensis & tolucensis & Quercus laurina \\
\hline Penstemon gentianoides & Cirsium jorullensis & \\
\hline Lupinus montanus & Geranium & \\
\hline Draba jorullensis & potentillaefolium & \\
\hline
\end{tabular}

\section{Previous palaeoecological studies}

Palaeoenvironmental research in the Basin of Mexico has been carried out mainly in the southern section, in the sub-basin of Lake Chalco (Figure 1a). The catchment of this lake includes the western slopes of Iztaccíhuatl (Figure 1a). Diatoms, pollen and the geochemistry and magnetic properties of several dated lacustrine sequences in Lake Chalco have been studied recently (Lozano-García et al., 1993; Lozano-García and OrtegaGuerrero, 1994; 1997; Caballero and Ortega, 1998; OrtegaGuerrero and Newton, 1998). Pollen data in the cores indicate changes in the early and mid-Holocene forest communities (Lozano-García et al., 1993; Lozano-García and OrtegaGuerrero, 1994; 1997; Lozano-García, 1996; Sosa-Nájera, 2001). The late Holocene vegetation record is disrupted by human activity in the sub-basin, but other proxy indicators such as diatoms suggests an increase in water-level.

Two Holocene pollen sequences from the middle slopes of mountains have been studied in neighbouring basins: Tláloc crater $(3100 \mathrm{~m})$ on the eastern flank of Malinche volcano (Ohngemach and Straka, 1983) and Lake Quila (3010 m) in the Zempoala volcanic range (Almeida-Leñero, 1997) (Figure 1a).

\section{Methods}

We obtained a 450-cm sediment core using an Eijkelkamp soil sampler. In the laboratory samples for pollen analysis were taken at $5-\mathrm{cm}$ intervals. Lycopodium clavatum spores were added in $2-\mathrm{cm}^{3}$ sediment samples at the beginning of the technique. Pollen was extracted from the samples using standard palynological techniques (Batten, 1999). In most samples a pollen sum of 500 grains was reached, although some levels were barren of pollen. Samples below a depth of $382 \mathrm{~cm}$ contained no pollen. The pollen sum was calculated based on the arboreal (AP) and non-arboreal pollen (NAP) excluding aquatic and subaquatic taxa. Calculation of pollen percentages and concentrations was carried out with Tilia and Tilia-Graph programs (Grimm, 1992). Pollen zones were established by CONISS Zonation (Grimm, 1987).

Fragments of charcoal and pollen extract, processed according to Brown et al. (1992), were submitted to Beta Analytic for AMS radiocarbon dating (Table 2).

\section{Results}

\section{Chronology and lithology}

The sequence is dominated by dark grey sandy loams, presumably colluvially reworked volcanic ashes (see Figure 3). Near the bottom the sediments are gravelly sandy loams. We interpret the coarse gravel of the bottom of the sequence as ground moraine deposits.

The sediment sequence covers the last $11000 \mathrm{cal}$. yr BP. The chronology is based on three AMS radiocarbon dates from the core itself plus the reported age (c. $5700 \mathrm{cal}$. yr BP) of a plinian pumice deposit from Popocatépetl volcano that was unequivocally identified in our core at a depth of $173 \mathrm{~cm}$ (Table 2). This pumice has been radiocarbon dated in the area between Popocatépetl and Iztaccíhuatl (Heine, 1975; Lambert and Valastro, 1976; Siebe et al., 1996), with calibrated ages ranging from 5525 to 5810 cal. yr BP (Table 2). The calibrated radiocarbon ages increase with depth and display a general linear relationship (Figure 2), with the exception of a sample near the bottom of the core $(431 \mathrm{~cm})$. We believe this age is 
Table 2 Radiocarbon dates of Agua El Marrano core and radiocarbon dates of the $\sim 5000$ year old marker pumice layer from Popocatépetl volcano

\begin{tabular}{|c|c|c|c|c|c|}
\hline Sample & Laboratory code & $\begin{array}{l}\text { Radiocarbon date } \\
\text { (yr BP) }\end{array}$ & $\begin{array}{l}\text { Calibrated } \\
\text { date }(\mathrm{yr} \mathrm{BP})^{\mathrm{a}}\end{array}$ & Material dated & Source \\
\hline Core 85 depth & Beta158794 & $3460 \pm 50$ & 3694 & Pollen & This paper \\
\hline Core 296 depth & Beta-113912 & $8870 \pm 80$ & 10023 & Charcoal & This paper \\
\hline Core 339 depth & Beta-113913 & $9290 \pm 150$ & 10454 & Charcoal & This paper \\
\hline Core 431 depth $^{\mathrm{b}}$ & Beta-122934 & $8020 \pm 90$ & 9030 & $\begin{array}{l}\text { Organic coating on root } \\
\text { channel }\end{array}$ & This paper \\
\hline $\begin{array}{l}\text { N side of Popocatépetl } \\
\text { (Paso de Cortéz) }\end{array}$ & Hv- 4883 & $4805 \pm 60$ & 5525 & Charcoal inside pumice & Heine (1975) \\
\hline NW side of Popocatépetl & $\begin{array}{l}\text { Tx-1671 } \\
\text { Tx-1671 } \\
\text { Tx-1671 (weighted } \\
\text { av.) }\end{array}$ & $5081 \pm 45$ & 5750 & $\begin{array}{l}\text { Paleosol immediately below } \\
\text { yellow pumice lapilli }\end{array}$ & $\begin{array}{l}\text { Lambert and } \\
\text { Valastro (1976) }\end{array}$ \\
\hline NE side of Popocatépetl & $\begin{array}{l}\text { A- } 8321 \\
\text { A- } 8321\end{array}$ & $\begin{array}{l}5080 \pm 85 \\
4965 \pm 65\end{array}$ & $\begin{array}{l}5725 \\
5832\end{array}$ & $\begin{array}{l}\text { Charcoal from surge } \\
\text { sequence }\end{array}$ & Siebe et al., 1996 \\
\hline
\end{tabular}

\footnotetext{
${ }^{\text {a }}$ Radiocarbon calibration (1 sigma) using CALIB (Stuiver and Reimer, 1993; version 4.1) and calibration data set by Stuiver et al. (1998).

${ }^{\mathrm{b}}$ Rejected date.
}

anomalously young, presumably resulting from contamination from higher levels, and therefore it is not included in the age model.

According to the age model (Figure 2), sediment accumulation in the moraine depression could have begun around 11500 cal. yr BP, following the retreat of the glacier from its end moraine. However, we believe that sedimentation started some time later (probably around $11000 \mathrm{cal}$. yr BP) based on the observation that erosion rates of moraine slopes (and therefore accumulation rates of colluvium at the base of moraines) are usually highest immediately after glacier recession, under periglacial conditions (Ballantyne, 2002).

In addition, the exposure age of a boulder from the enclosing moraine ridge, located $15 \mathrm{~m}$ from the coring site, was determined by means of the cosmogenic nuclide ${ }^{36} \mathrm{Cl}$ (Zreda and Phillips, 2000). The boulder yielded $10000 \pm 500{ }^{36} \mathrm{Cl} \mathrm{kyr}$ BP, which falls within the recessional phase of Milpulco-1 advance of Iztaccíhuatl (Vázquez-Selem, 2000) and is roughly equivalent to $9000{ }^{14} \mathrm{C}$ yr BP. The exposure age appears to be younger than the true age of moraine formation, which is a common situation in surface exposure dating of moraines (Zreda et al., 1994; Putkonen and Swanson, 2003).

\section{Palynology}

A total of 66 pollen taxa were identified in the Agua El Marrano core at different taxonomic levels. Pollen data are presented in a relative percentage summary pollen diagram (Figure 3). Taxa are grouped according to their ecological

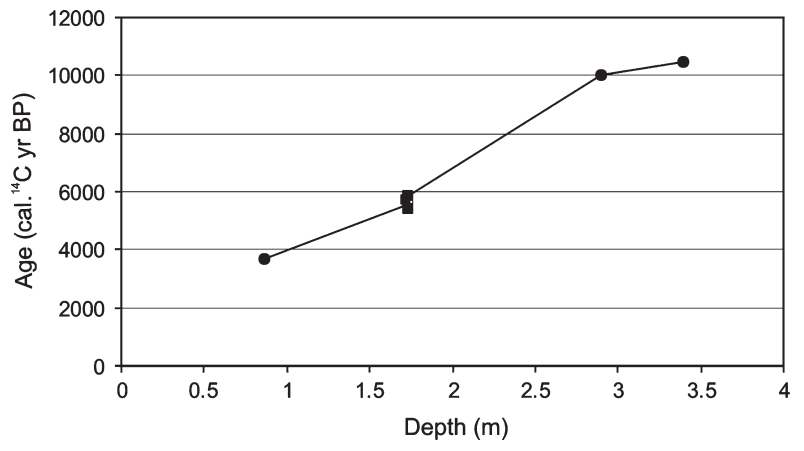

Figure 2 Age model. Average depth versus calibrated AMS ${ }^{14} \mathrm{C}$ dates. Solid circles correspond to samples of Agua el Marrano core and solid squares to the $\sim 5700$ calibrated radiocarbon pumice habits to show changes in plant communities. Alpine grassland taxa cluster in group 1; taxa growing in the Pinus hartwegii forest, but which can also reach higher elevations towards the lower alpine grasslands, constitute group 2; taxa of the coniferous forests are included in group 3; mesophytic forest taxa make up group 4; elements indicative of disturbance and fern spores are arranged in group 5; and taxa indicative of swampy conditions group 6 (Figure 3).

Results of the modern pollen rain at the site correspond to the $0-\mathrm{cm}$ sample in the summary diagram (Figure 3). The composition is simple, with pine pollen dominant (75\%). Other taxa that are not present at the site but contribute with low percentages to the pollen rain are: Quercus $(10 \%)$ and Alnus $(4.8 \%)$. Among the taxa present in the modern vegetation, which are part of the pollen rain, are: Ceratium, Conyza and Eryngium within the herbs, and the pine epiphytic Arceuthobium aff. globosum.

No pollen was found at the bottom of the sequence from 440 to $390 \mathrm{~cm}$, where the lithology is gravelly loamy sand. Pollen deposition starts at $382 \mathrm{~cm}$ depth (c. 10900 cal. yr BP according to the age model), after the retreat of the glacier. During the last $9800{ }^{14} \mathrm{C}$ yr pollen concentration varied between 46821 and 1681 grains per $\mathrm{cm}^{3}$. An average pollen accumulation rate of 682 grains per $\mathrm{cm}^{2}$ per year was calculated (Figure 3).

Pollen zonation was established by CONISS, a stratigraphically constrained cluster analysis (Grimm, 1987).

Zone 1 lasts from c. 10900 cal. yr BP to c. 8000 cal. yr BP (382-235 cm depth). Pollen deposition began at $382 \mathrm{~cm}$. This zone is characterized by the highest percentages of nonarboreal pollen $(>80 \%)$, mainly Poaceae with lower values of Draba, Arenaria and Plantago, which are elements from groups 1 and 2. The alpine bunchgrassland was therefore present near the coring site during the Pleistocene-Holocene transition. It was clearly established by 10900 cal. yr BP and remained through c. 8000 cal. yr BP. Alpine grassland fossil pollen rain at other high-altitude sites of the MVB shows similar percentages (Straka and Ohngemach, 1989; Caballero et al., 2001). Arboreal taxa belonging to group 3, Pinus, Quercus and Alnus vary between $7.6 \%$ and $1 \%$ and are probably related to upslope pollen transport. Pollen concentration fluctuates between 5500 grains per $\mathrm{cm}^{3}$ at the base of the sequence $(382 \mathrm{~cm})$ and 26000 grains per $\mathrm{cm}^{3}$ before the deposition of the grey tephra at $290 \mathrm{~cm}$. A reduction in the 


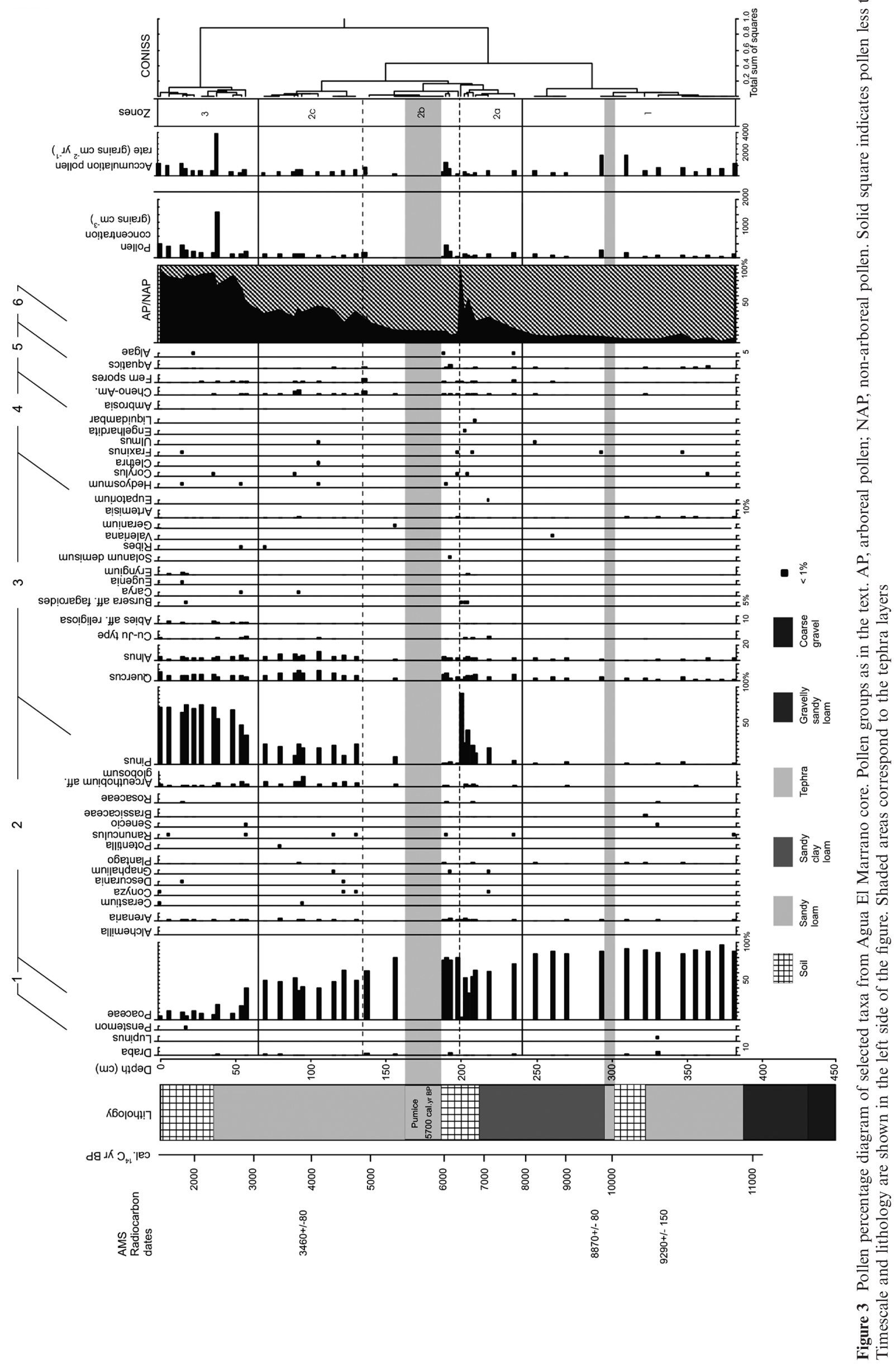


average pollen accumulation rate is observed after this volcanic event.

Zone 2 spans c. 8000 cal. yr BP to c. 3000 cal. yr BP (235$70 \mathrm{~cm}$ depth). Changes in the pollen stratigraphy allow the subdivision of this zone into three subzones. In the basal subzone 2a from c. 8000 to c. 6500 cal. yr BP $(235-202 \mathrm{~cm}$ depth) the pollen data show an increase in coniferous forest elements. A trend towards higher values of arboreal pollen with Pinus (4.6-21.5\%), Quercus (4.6-7.6\%), Alnus (4.6-2.6\%) and Abies aff. religiosa $(<1 \%)$ begins in the first two samples from c. 8000 to $c .7200$ cal. yr BP. Indicators of flooding conditions at the site, included in group 6, increase in this period, which corresponds to the Milpulco-2 glacial advance. Between c. 7200 and c. 6500 cal. yr BP Pinus show a trend towards higher values, reaching 92\%. There are also slight increases in Quercus, (8\%), Alnus (3.8\%) and Cu.-Ju. type (3\%), along with Eryingium (2.5\%) and Arcethobium aff. globosum (3\%). This pollen assemblage is similar to the Pinus hartwegii forest modern pollen rain (Palacios, 1977; Ohngemach and Straka, 1983; Tovar, 1987). Arceuthobiumn globosum, a characteristic element in the pollen rain of the Pinus hartwegii community, is considered to be an indicator of this coniferous forest (Ohngemach and Straka, 1983; Almeida-Leñero, 1997). Higher representation of these taxa is indicative of climate amelioration, with pine forest growing near or at the site for a short period. The mesophytic forest assemblage (group 4) is present in low percentages during this period. Hedyosmum and Engelhardtia, taxa of group 4, indicate mountainous humid environments and are no longer part of the modern mesophytic forests of the central Mexican highlands (Rzedowski and Rzedowski, 2001), but are found growing today in the tropical southern regions of Mexico. During this peak of arboreal taxa, elements of group 6, which indicate swampy conditions, display reduced values, suggesting a period similar to modern conditions. Pollen concentration decreases compared with the previous zone, reaching its minimum value of the sequence $\left(1700\right.$ grains per $\left.\mathrm{cm}^{3}\right)$ in the uppermost sample $(202 \mathrm{~cm}, c .6500$ cal. yr BP). This supports the interpretation of reduced water accumulation in the depression.

Subzone $2 \mathrm{~b}$ has an interpolated age of $c .6500$ to $c .5000 \mathrm{cal}$. yr BP $(202-139 \mathrm{~cm}$ depth). The boundary between $2 \mathrm{a}$ and $2 \mathrm{~b}$ is given by the sudden reduction of pine pollen, the re-establishment of previous percentages of grass pollen $(80 \%)$ and a decrease in the percentages of group 3. Pollen stratigraphy indicates the return of alpine grasslands at the site. Pollen concentration values are higher (44870-6947 grains per $\left.\mathrm{cm}^{3}\right)$. The pollen assemblage was interrupted by the deposition of the 5700 cal. yr BP tephra and after this event a reduction in the pollen taxa diversity is evident.

Subzone 2c spans c. 5000 to c. 3000 cal. yr BP $(139-70 \mathrm{~cm}$ depth). In this subzone, lower values of groups 1 and 2 and an increase in group 3 elements are observed, along with an increase of forest elements. Montane forest pollen becomes more abundant: Pinus (12-37\%), Quercus (5-12\%) and Alnus $(4-11 \%)$. The record of the epiphytic Arcethobium aff. globosum is present continuously at significant values (3-13\%). Among the herbs, the percentage of the grasses gradually decreases from $60 \%$ to $45 \%$. A combination of taxa from the alpine grasslands and the coniferous forest elements established around the site, suggesting an upslope movement of the vegetation belts. Pollen concentration fluctuates between 8000 and 15000 grains per $\mathrm{cm}^{3}$, with an average pollen accumulation rate of 500 grains per $\mathrm{cm}^{2}$ per year.

Zone 3 covers the last $c .3000$ cal. yr BP (70-0 cm depth). It documents the dominance of coniferous forest components (group 3) in the pollen spectra, and culminates with the highest values of arboreal pollen (51-88\%). The main montane elements Pinus (58-76\%), Quercus (4.9-7.8\%), Alnus (3.5$8.5 \%)$, Abies $(1.1-2.2 \%)$ and Cu.-Ju. type $(1-2.8 \%)$ are continuously present in this part of the sequence. Pollen of grasses and herbaceous taxa show the lowest values of the record $(5-17 \%)$. The late Holocene pollen assemblages are similar to the modern pollen rain at the site, indicating that the Pinus hartwegii forest was present during this period. High pollen concentration values are documented with a significant increase $\left(156800\right.$ grains per $\left.\mathrm{cm}^{3}\right)$ at $38 \mathrm{~cm}$.

\section{Discussion}

Pollen analysis of Agua El Marrano sediments provides information about the Holocene vegetation changes in the highlands of the Basin of Mexico, in particular on the establishment and altitudinal fluctuation of the alpine grassland and the upper forest. According to the age model, sediment accumulation behind the Milpulco-1 moraine in Agua El Marrano valley began around 11500 cal. yr BP, however we believe this occurred some time later, probably around 11000 cal. yr BP, when Milpulco-1 glaciers were receding on Iztaccíhuatl (Vázquez-Selem, 2000).

The absence of pollen in the lower part of the core (450$382 \mathrm{~cm} \mathrm{depth)} \mathrm{supports} \mathrm{the} \mathrm{existence} \mathrm{of} \mathrm{marked} \mathrm{periglacial}$ conditions immediately after the retreat of the glacier and for the next few hundred years. Temperatures $c .4{ }^{\circ} \mathrm{C}$ colder than present have been estimated for the Milpulco-1 advance ( $\sim 12000$ to $\sim 10500$ cal. yr BP) based on the altitudes of the equilibrium line of glaciers (Vázquez-Selem, 2000). Assuming that the altitude of the timberline was controlled by temperature, and applying a lapse rate of $6^{\circ} \mathrm{C} / \mathrm{km}$, temperatures $\sim 4^{\circ} \mathrm{C}$ colder than present may have produced a timberline $\sim 700 \mathrm{~m}$ lower than today, i.e., at $\sim 3300 \mathrm{~m}$ (Figure 4). This is compatible with two vegetation-based estimates of cooling from the region. Using pollen spectra (by Ohngemach and Straka, 1983) from Tláloc cráter at $3100 \mathrm{~m}$ on Malinche volcano, D'Antoni (1993) estimated temperatures $3.5-2^{\circ} \mathrm{C}$ lower than present between $\sim 11500$ and $\sim 9500$ cal. yr BP ( $\sim 10000$ to $\left.\sim 8500{ }^{14} \mathrm{C} \mathrm{yr} \mathrm{BP}\right)$. In the Petén lowlands of northern Guatemala, Leyden et al. (1993) calculated temperatures $3.0-4.7^{\circ} \mathrm{C}$ lower than present between $\sim 12500$ and 10200 cal. yr BP $\left(10500-9000{ }^{14} \mathrm{C}\right.$ yr BP).

Temperatures during the earliest Holocene apparently were too low for forest development at $3860 \mathrm{~m}$. However, by c. 10900 cal. yr BP, alpine grasslands had developed at the site and existed there for the next 3000 years. No major change in vegetation composition is observed during the timespan of the Milpulco-2 glacier advance (c. 8300-7300 cal. yr BP), which formed moraines at elevations between 4000 and $4300 \mathrm{~m}$ in the same valley (Figure 1C). Temperatures reconstructed from the equilibrium line altitudes of glaciers are $3.3 \pm 0.7^{\circ} \mathrm{C}$ and $2.6 \pm$ $0.6^{\circ} \mathrm{C}$ lower than present for the early (maximum) and recessional stages of the Milpulco- 2 advance, respectively (Vázquez-Selem, 2000). A cooling of $\sim 3^{\circ} \mathrm{C}$ probably depressed the timberline $\sim 500 \mathrm{~m}$ below its modern elevation, which is consistent with the absence of forest around the coring site. However, the cooling was not sufficient to eliminate the alpine grassland from the area.

In summary, the early Holocene timberline position at Iztaccíhuatl volcano is estimated at between $c$. 700 and c. $500 \mathrm{~m}$ below its modern elevation (Figure 4). Similar calculations based on pollen records have been reported for other tropical highlands (van der Hammen and González, 1960; van Geel and van der Hammen, 1973; Hooghiemstra, 


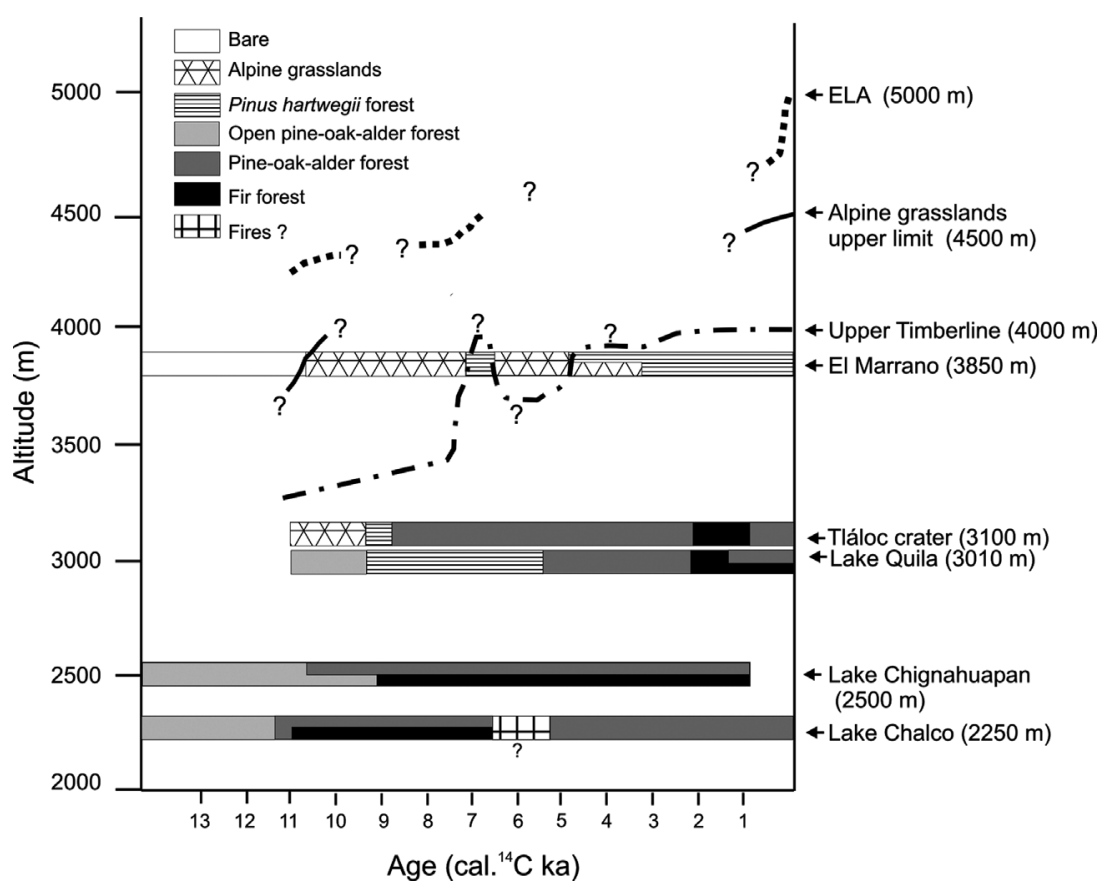

Figure 4 Vegetation records based on pollen diagrams from eastern-central Mexico. Location is shown on Figure 1. References of the sites are as follows: Agua El Marrano (this paper); Tlaloc crater (Ohngemach, 1977; Straka and Ohngemach, 1989); Lake Quila (AlmeidaLeñero, 1997); Lake Chignahuapan (Lozano-García et al., 2003); Lake Chalco (Lozano-García et al., 1993; Lozano-García and OrtegaGuerrero, 1994, 1997; Sosa-Nájera, 2001). Equilibrium line altitude (ELA) of glaciers of Iztaccíhuatl (Vázquez-Selem, 2000). The ELA, the upper limit of alpine grasslands and the upper timberline are indicated with different types of lines

1984; Islebe and Hooghiemstra, 1997; Flenley, 1998; Wille et al., 2001).

Comparing our high-altitude $(3860 \mathrm{~m})$ pollen data with records from the mid slopes of other mountains in the region and with those from the lacustrian beds of the Basin of Mexico (Lake Chalco, $2200 \mathrm{~m}$ ), the following conclusions may be drawn. During the period of the Milpulco-1 glacial advance (c. 10250 to $c .9000{ }^{14} \mathrm{C}$ yr BP) on Iztaccíhuatl, a trend towards higher percentages of arboreal taxa (mainly pine and oak) is reported in the lacustrian pollen sequences (Figure 4). For the early Holocene from 10900 to 8000 cal. yr BP, while colonization of the alpine grasslands took place in Agua El Marrano, the improvement in temperature as a response to the Northern Hemisphere maximum insolation (Kutzbach, 1983), made the expansion of the pine-oak-alder and fir forests possible in the lowlands (Figure 4). At Lake Quila (3010 m), a midaltitude site located $30 \mathrm{~km}$ southwest of the basin of Mexico and $60 \mathrm{~km}$ west-southwest of Iztaccíhuatl (Figure 1A), simultaneous reduction in the pine-oak-alder forest and an increase in the pine forest is documented by $c .10400$ cal. yr BP ( 9250 ${ }^{14} \mathrm{C}$ yr BP) (Almeida et al., 1994). Pollen sequences Tlaloc I and II of La Malinche volcano (3100), $60 \mathrm{~km}$ east of Iztaccíhuatl volcano (Figure 1a), are characterized by the presence of alpine grassland before c. 9500 cal yr BP ( 8500 ${ }^{14} \mathrm{C}$ yr BP), and afterwards by the expansion of the Pinus hartwegii (Ohngemach, 1977; Straka and Ohngemach, 1989). The data from Malinche volcano (but not those from Quila) suggest that the upper timberline in the earliest Holocene was situated near $3000 \mathrm{~m}$. During the early Holocene increasing temperature and precipitation compared with the late glacial environments (Metcalfe et al., 2000) promoted forest expansion in the mid-altitude areas of the TMVB, but the forest did not reach sites as high as Agua El Marrano until c. 7200 cal. yr BP.

A change in pollen composition is detected by 7200 cal. yr BP coinciding with the end of the Milpulco-2 advance (Figure 3). Elements of the coniferous forests (Table 1) became more abundant, indicating that these communities were near or at the site during early-mid Holocene, 7200-6500 cal. yr BP (6500-6000 ${ }^{14} \mathrm{C}$ yr BP). We interpret this event as a combination of higher temperatures - consistent with glacier recession - and increased moisture, recorded by different proxies from central Mexico between $\sim 7800$ and $\sim 6800$ cal. yr BP $(7000-$ $6000{ }^{14} \mathrm{C}$ yr BP) (Metcalfe et al., 2000; Caballero et al., 2002). Between c. 6500 and 5000 cal. yr BP a return of the alpine grasslands to the coring area is documented (Figure 3). Based on other records from central Mexico, we interpret this midHolocene lowering of the timberline to be a result of drier conditions recorded by different proxies in the region (Metcalfe et al., 2000; Caballero et al., 2002).

From c. 7200 to 6500 cal. yr BP pine forest near Agua El Marrano correlates with low lake levels in Lake Chalco and a slight reduction in the forest cover around this lake. At the mid-altitude site of Lake Quila dry conditions are not evident at this time. Between $\sim 6800$ and $\sim 5700$ cal yr BP (6000$5000{ }^{14} \mathrm{C}$ yr BP) indicators of drier conditions can be found in several lacustrian pollen sequences of central Mexico (Xelhuantzi-López, 1994; Metcalfe et al., 2000; Sosa-Nájera, 2001).

After 5700 cal. yr BP $\left(5000{ }^{14} \mathrm{C}\right.$ yr BP) there was a gradual increase of taxa from the coniferous forest, coeval with an increase in moisture in the region. This trend culminates with the establishment of the Pinus hartwegii forest at the site since around 3000 cal. yr BP. Pinus hartwegii has been reported as a pioneer and also a climax tree at high altitude in the mountains of central Mexico (Rodíguez-Trejo and Fulé, 2003). Agua El Marrano pollen spectra indicate no major change in this community during the last 3000 years, in contrast to the pollen data of the lakes in the basin of Mexico where evidence of human impact is well documented (González-Quintero and Fuentes-Mata, 1980; Niederberger, 1987; Lozano-García et al., 1993; Lozano-García and Ortega-Guerrero, 1994; LozanoGarcía and Xelhuantzi-Lóplez, 1997; Sosa-Nájera, 2001). 
The establishment of the Pinus hartwegii forest in Agua El Marrano at 3000 cal. yr BP corresponds to a period of higher lake levels in Lake Chalco. Human impact around the lake produced lower values of pine and oak pollen and higher numbers of disturbance taxa (Cheno.-Am. and Asteraceae) in the lake Chalco pollen spectra, suggesting deforestation in the lowlands (Lozano-García et al., 1993; Lozano-García and Ortega-Guerrero, 1994; 1997; Lozano-García, 1996; SosaNájera, 2001). The development of Pinus forests at higher elevation also corresponds with a trend towards moister and cooler climate that culminates with the establishment of Abies forest around 2000 cal. yr BP in lakes Quila and Zempoala (Almeida-Leñero, 1997), and between $\sim 2800$ and $\sim 1300$ cal. yr BP (2670-1365 ${ }^{14} \mathrm{C}$ yr BP) in Tlaloc crater (Ohngemach and Straka, 1983; Heine, 1985; D’Antoni, 1993).

In summary, while a strong human impact is well documented by the pollen data from the lakes in the lower parts of the Basin of Mexico $(2200 \mathrm{~m})$ since $c .3000 \mathrm{cal}$. yr BP, there is no evidence of human disturbance in the high-elevation pollen record of Agua El Marrano (3860 m). At present human impact remains low at the site because of difficulty of access and a relatively severe climate. Logging and grazing have taken place in the upper forest of Iztaccíhuatl in the last few decades, but agriculture has not been practiced above $3300 \mathrm{~m}$.

\section{Conclusions}

The pollen analysis of the high-altitude Agua El Marrano sequence reflects a continuous history of vegetation spanning the last $\sim 11000$ cal. yr BP. The pollen diagram shows the establishment of the alpine grasslands by 10900 cal. yr BP (9800 ${ }^{14} \mathrm{C}$ yr BP), when Milpulco-1 glaciers were receding. The permanence of these grasslands until c. 7200 cal. yr BP likely reflects cooler conditions than at present, which is consistent with the glacial record of Iztaccíhuatl during the first half of the Holocene. The development of coniferous forest from 7200 to 6500 cal. yr BP at or near the site suggests a sudden temperature improvement immediately after the Milpulco-2 glacial advance, in combination with a wet climate across central Mexico. Conditions for forest growth deteriorated rapidly after $7200 \mathrm{cal}$. yr BP, and the alpine grasslands returned to the area for the next 1000-1500 years, apparently in connection with drier climates recorded across central Mexico around the mid-Holocene (c. 6000 cal. yr BP). There is evidence of the continuous presence of the Pinus forest at the coring site for the last 3000 years. When compared with other proxies from the region, the pollen record of Agua El Marrano suggests that the upper timberline in central Mexico has fluctuated significantly during the Holocene in response to the complex interplay of temperature and precipitation, and reached its modern elevation only in the last third of the Holocene.

\section{Acknowledgements}

This research was supported by CONACyT (grants G-28528-T and 40346) and by the National Science Foundation (grant 9422220). We thank Alejandro Velázquez and Martha Escamilla for their support in interpreting vegetation data and Margarita Caballero, Alejandro Velázquez and Barbara Martiny for their critical comments and suggestions on the manuscript. Susana Sosa prepared all the palynological samples. The constructive suggestions of K.D. Bennett and one anonymous reviewer were most helpful.

\section{References}

Almeida, L., Cleff, A., Herrera, A., Velázquez, A. and Luna, I. 1994: El zacatonal alpino del volcán Popocatépetl, México y su posición en las montañas tropicales de América. Phytocoenologia 23, 391-436.

Almeida-Leñero, L. 1997: Vegetación, fitogeografía y paleoecología del zacatonal alpino y bosques montanos de la región central de México. Unpublished Ph.D. Thesis, Universiteit van Amsterdam. Ballantyne, C.K. 2002: Paraglacial geomorphology. Quaternary Science Reviews 21, 1935-2017.

Batten, D.J. 1999: Small palynomorphs. In Jones, T.P. and Rowe, N.P., editors, Fossil plants and spores: modern techniques. London: The Geological Society, 15-19.

Beaman, J.H. 1962: The timberlines of Iztaccíhuatl and Popocatépetl, Mexico. Ecology 43, 337-85.

Bradbury, J.P. 2000: Limnologic history of Lago de Patzcuaro, Michoacan, Mexico for the past 48,000 years: impacts of climate and man. Palaeogeography, Palaeoclimatology, Palaeoecology 163, $65-95$.

Brown, T.A., Farwell, G.W., Grootes, P.M. and Schmidt, F.H. 1992: Radiocarbon AMS dating pollen extracted peat samples. Radiocarbon 34, 550-56.

Caballero, M.M. 1995: Late Quaternary Paleolimnology of Lake Chalco, The Basin of Mexico: new evidence for paleoenvironmental and paleoclimatic change in central Mexico during the last 45000 years. Unpublished Ph.D. dissertation, University of Hull, UK.

Caballero, M. and Ortega-Guerrero, B. 1998: Lake levels since 40000 ago at Chalco Lake, near Mexico City. Quaternary Research 50, 90-106.

Caballero M., Macías, J.L., Lozano-García, S., UrrutiaFucugauchi, J. and Castañeda, B.R. 2001: Late PleistoceneHolocene volcanic stratigraphy and paleoenvironments of the upper Lerma basin, Mexico. Special Publications of the International Association of Sedimentologists 30, 247-61.

Caballero, M.M., Ortega, B., Valadéz, F., Metcalfe, S., Macías, J.L. and Sugiura, Y. 2002: Sta. Cruz Atizapán: a 22-ka lake level record and climatic implications for the late Holocene human occupation in the upper Lerma basin, central Mexico. Palaeogeography, Palaeoclimatology, Palaeoecology 186, 217-35.

Cruz-Cisneros, R. 1969: Contribución al conocimiento de la ecología de los pastizales en el Valle de México. Unpublished MS Thesis, Instituto Politécnico Nacional, México.

D'Antoni, H.L. 1993: Paleotemperatures of La Malinche: a palynological hypothesis. Grana 32, 354-58.

Ferrari, L. 2000: Avances en el conocimiento de la Faja Volcánica Transmexicana durante la última década. Boletín de la Sociedad Geológica Mexicana 53, 84-92.

Ferrari, L., Garduño, V.H., Pasquare, G. and Tibaldi, A. 1994: Volcanic and tectonic evolution of Central Mexico - Oligocene to present. Geofisica Internacional 33, 91-115.

Flenley, J.R. 1998: Tropical forest under the climates of the last 30000 years. Climate Change 39, 177-98.

González-Quintero, L. and Fuentes-Mata, M. 1980: El Holoceno en la porción central de la cuenca del valle de México. Memorias del III Coloquio sobre Paleobotánica y Palinología. Colección Científica 86: Instituto Nacional de Antropología e Historia, 195200.

Grimm, E.C. 1987: CONISS: a FORTRAN program for stratigraphically constrained cluster analysis by the method of incremental sum of squares. Computer and Geosciences 13, 13-35. 1992: TILIA 2 software. Springfield IL: Illinois State Museum.

Grimm, E., Lozano-García, S., Behling, H. and Markgraf, V. 2001: Holocene vegetation and climate variability in the Americas. In Markgraf, V., editor, Interhemispheric climate linkages. San Diego CA: Academic Press, 325-63.

Heine, K. 1975: Studien zur jünquartären Glazialmorphologie mexikanischer Vulkane. Mit einem Ausblick auf die Klimaentwicklung. Wiesbaden: Franz Steiner. 
1985: Neue absolute Daten zur holozänen Gletscher-, Vegetations- und Klimageschichte zentralmexikanischer Vulkane. Regensburger Geographische Schriften 19/20, 79-92.

— 1988: Late Quaternary glacial chronology of the Mexican volcanoes. Die Geowissenschaften 7, 197-205.

Hooghiemstra, H. 1984: Vegetational and climatic history of the High Plain of Bogotá, Colombia: a continuous record of the last 3.5 million years. Dissertactiones Botanicae, Vol. 79. Vaduz: J. Cramer, $368 \mathrm{pp}$.

Islebe, G.A. and Hooghiemstra, H. 1997: Vegetation and climate history of montane Costa Rica since the last glacial. Quaternary Science Reviews 16, 589-604.

Islebe, G.A. and Velázquez, A. 1994: Affinity among mountain ranges in Megamexico: a phytogeographical scenario. Vegetatio 115, 1-9.

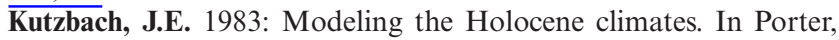
S.C., editor, Late Quaternary environments of the United States, Vol. II: The Holocene. New York: Longman, 271-77.

Lambert, P.W. and Valastro, S. 1976: Stratigraphy and age of Upper Quaternary tephras on the northwest side of Popocatépetl Volcano, Mexico. In American Quaternary Association, Fourth Biennial Meeting. Tempe, AZ: American Quarters Association (AMQUA) $143 \mathrm{pp}$.

Lambert, W. 1986: Descripción preliminar de los estratos de tefra en Tlapacoya. In Lorenzo, J.L. and Mirambell, L., editors, Tlapacoya: 35000 años de historia del lago de Chalco, México. Colección Científica 115: Mexico DF: Instituto Nacional de Antropología e Historia, 77-100.

Lauer, W. 1978: Timberline studies in Central Mexico. Artic and Alpine Research 102, 383-96.

Lauer, W. and Klaus, D. 1975: Geoecological investigations on the timberline of Pico de Orizaba. Artic and Alpine Research 74, 31530 .

Leyden, B.W., Brenner, M., Hodell, D.A. and Curtis, H.C. 1993: Late Pleistocene climate in the Central American lowlands. In Swart, P.K., Lohmann, K.C., McKenzie, J. and Savin, S., editors, Climate change in continental isotopic records. Geophysical Monograph 78. Washington DC: American Geophysical Union, $165-78$.

Lorenzo, J.L. 1964: Los glaciares de México. México: Instituto de Geofísica, Universidad Nacional Autónoma de México.

Lozano-García, M.S. 1996: La vegetación del Cuaternario tardío en el centro de México: registros palinológicos e implicaciones paleoclimáticas. Boletín de la Sociedad Botánica de México 58, 113-28.

Lozano-García, M.S. and Ortega Guerrero, B. 1997: Late Quaternary environmental changes of the central part of the Basin of Mexico. Correlation between Texcoco and Chalco basins. Review of Palaeobotany and Palynology 99, 77-93.

Lozano-García, M.S. and Xelhuanzti, L.M.S. 1997: Some problems in the late Quaternary pollen records of central Mexico: Basin of Mexico and Zacapu. Quaternary International 43/44, 117-23.

Lozano-Garcia, M.S., Ortega-Guerrero, B., Caballero, M. and Urrutia Fucugauchi, J. 1993: Late Pleistocene and Holocene paleoenvironments of Chalco lake. Quaternary Research 40, $332-42$.

Lozano-Garcia, M.S., Caballero, M.M., Ortega, G.B., Valadez, F. and Suigura, Y. 2003: Late Quaternary paleoecology of the Upper Lerma basin, central Mexico. In Third International Limnogeology Congress. 29 March-2 April 2003, Tucson AZ, 274 pp.

Lozano-García, S. and Ortega Guerrero, B. 1994: Palynological and magnetic susceptibility records of Chalco Lake, central Mexico. Palaeogeography, Palaeoclimatology, Palaeoecology 109, 177-91.

Martin-Del Pozzo, A.L., Cifuentes-Nava, G., Cabral-Cano, E., Sánchez-Rubio, G., Reyes, M., Martínez-Bringas, A., Garcia, E. and Arango-Galvan, C. 2002: Volcanomagnetic signals during the recent Popocatépetl (México) eruptions and their relation to eruptive activity. Journal of Volcanology and Geothermal Research 113, 415-28.

Metcalfe, S.E., Street-Perrott, F.A., Perrot, R.A. and Harkness, D.D. 1991: Palaeolimnology of the Upper Lerma Basin, Central Mexico: a record of climatic change and anthropogenic disturbance since 11,600 yr BP. Journal of Paleolimnology 5, 197-218.

Metcalfe, S.E., O'Hara, S.L., Caballero, M. and Davis, S.J. 2000: Records of Late Pleistocene-Holocene in Mexico - a review. Quaternary Science Reviews 1, 699-721.

Mooser, F. 1967: Tefracronología de la cuenca de México para los últimos treinta mil años. Boletín, Instituto Nacional de Antropología e Historia 30, 12-15.

Niederberger, B.C. 1987: Paleopaysages et archeology pre-urbaine du Bassin de Mexico (Mexique). Centre d'Etudes Mexicaines et Centroamericaines. Collection Etudes Mésoaméricaines 1, 1-337. Nixon, G.T. 1989: The geology of Iztaccíhuatl volcano and adjacent areas of the Sierra Nevada and valley of Mexico. Geological Society of America Special Paper 219, 1-58.

Ohngemach, D. 1977: Pollen sequence of the Tlaloqua crater (La Malinche volcano, Tlaxcala, Mexico). Boletín de la Sociedad Botánica de México 36, 33-40.

Ohngemach, D. and Straka, H. 1983: Beiträge zur Vegetations- und Klimageschichte im Gebiet von Puebla-Tlaxcala. Pollenanaysen im Mexiko-Projekt. Wiesbaden: Franz Steiner.

Ortega-Guerrero, B. and Newton, A. 1998: Geochemical characterization of late Pleistocene and Holocene tephra layers from the Basin of Mexico, central Mexico. Quaternary Research $50,90-106$

Ortega-Guerrero, B., Thompson, R. and Urrutia-Fucugauchi, J. 2000: Magnetic properties of lake Chalco, central Mexico, and their paleoenvironmental implications. Journal of Quaternary Science 15, 127-40.

Palacios, Ch.R. 1977: Lluvia de polen moderno en diferentes habitats del Valle de México. Boletín de la Sociedad Botánica de México 36, 45-69.

Phillips, F.M., Zreda, M.G., Elmore, D. and Sharma, P. 1996: A reevaluation of cosmogenic ${ }^{36} \mathrm{Cl}$ production rates in terrestrial rocks. Geophysical Research Letters 23, 949-52.

Putkonen, J. and Swanson, T. 2003: Accuracy of cosmogenic ages for moraines. Quaternary Research 59, 255-61.

Rodríguez-Trejo, D.A. and Fulé, P.Z. 2003: Fire ecology of Mexican pines and a fire management proposal. International Journal of Wildland Fire 12, 23-37.

Rzedowski, G.C. and Rzedowski, J. 2001: Flora Fanerogámica del Valle de México. Instituto de Ecología A:C y Comisión Nacional para el Conocimiento y Uso de la Biodiversidad, Pátzcuaro (Michoacán) México.

Siebe, C., Abrams, M., Macias, J.L. and Obenholzner, J. 1996: Repeated volcanic disasters in Prehispanic time at Popocatépetl, central Mexico: past key to the future? Geology 24, 399-402.

Sosa-Nájera, S. 2001: Registro palinológico del Pleistoceno tardío-Holoceno en el extremo meridional de la cuenca de México: Paleoambientes e inferencias paleoambientales. Unpublished M.Sc. thesis Universidad Nacional Autónoma de México, México.

Straka, H. and Ohngemach, D. 1989: Late Quaternary vegetation history of the Mexican highland. Plant Systematic and Evolution $162,115-32$.

Stuiver, M. and Reimer, P.J. 1993: Extended 14C data base and revised calib $3.014 \mathrm{C}$ age calibration program. Radiocarbon 35 , 215-30

Stuiver, M., Reimer, P.J., Bard, E., Beck, J.W., Burr, G.S., Hughen, K.A., Kromer, B., McCormac, F.G., v.d. Plicht, J. and Spurk, M. 1998: INTCAL98 Radiocarbon age calibration 24000-0 cal BP. Radiocarbon 40, 1041-83.

Tovar, G.C. 1987: Lluvia de polen en el volcán Popocatépetl: un estudio a lo largo de un transecto altitudinal. Unpublished thesis, Universidad Nacional Autónoma de México, México.

van der Hammen, T. and González, E. 1960: Holocene and late glacial climate and vegetation of Páramo de Palacio (E. Cordillera, Colombia, S. America). Geologie en Mijnbouw 39, 737-45.

van Geel, B. and van der Hammen, T. 1973: Upper Quaternary vegetational and climatic sequence of the Fuquene area (Eastern Cordillera, Colombia). Palaeogeography, Palaeoclimatology, Palaeoecology 14, 9-92. 
Vázquez-Selem, L. 2000: Late Quaternary glacial chronology of Iztaccíhuatl volcano, central Mexico. A record of environmental change in the border of the tropics. Unpublished Ph.D. dissertation, Arizona State University.

Vázquez-Selem, L. and Heine, K. 2004: Late Quaternary glaciation in Mexico. In Ehlers, J and Gibbard, P.L., editors, Quaternary glaciations - extent and chronology, part III. South America, Asia, Africa, Australia, Antartica. Amsterdam: Elsevier, 233-42.

Velázquez, A., Toledo, V.M. and Luna, I. 2000: Mexican temperate vegetation. In Barbour, M.G. and Dwigth Billings, W., editors, North American terrestrial vegetation. Cambridge: Cambridge University Press, 573-92.

Velázquez, D.R. 2003: Evolución paleoambiental del lago de Cuitzeo durante el Pleistoceno tardío: Historia de la vegetación e implicaciones paleoclimáticas. Unpublished M.Sc. thesis, Universidad Michoacana de San Nicolás de Hidalgo, Morelia, México.

White, S.E. 1962: Late Pleistocene glacial sequence for the west side of Iztaccíhuatl, Mexico. Geological Society of America Bulletin 73, 935-58.
2002: Glaciers of Mexico. In Williams, R.S. and Ferrigno, J.G., editors, Satellite image atlas of the glaciers of the world glaciers of North America. U.S. Geological Survey Professional Paper 1386-J-3. J383-J405.

Wille, M., Hooghiemstra, H., Behling, H., van der Borg, K. and Negret, A.J. 2001: Environmental change in the Colombian subandean forest belt from 8 pollen records: the last $50 \mathrm{kyr}$. Vegetation History and Archaeobotany 10, 61-77.

Xelhuantzi-López, M.S. 1994: Estudio palinológico de cuatro sitios ubicados en la cuenca de Zacapu: fondo ciénaga, contacto Lomas ciénaga, pantano interno y Loma Alta. Cuadernos de Estudios Michoacanos 6, 81-93.

Zreda, M.G. and Phillips, F.M. 2000: Cosmogenic nuclide buildup in surficial materials. In Noller, J.S., Sowers, J.M., Lettis, W.M., editors, Quaternary geochronology: methods and applications. Washington DC: American Geophysical Union, 61-76.

Zreda, M.G., Phillips, F.M. and Elmore, D. 1994: Cosmogenic $36 \mathrm{Cl}$ accumulation in unstable landforms. 2. Simulations and measurements on eroding moraines. Water Resources Research 30, $3127-36$. 